\title{
PENGELUARAN WISATAWAN ASAL MALAYSIA DI BANDUNG
}

\author{
Horas Djulius ${ }^{1}$, Bilal Fajar Nugraha ${ }^{2}$ \\ ${ }^{1}$ Fakultas Ekonomi dan Bisnis Universitas Pasundan, horasdjulius@unpas.ac.id \\ ${ }^{2}$ Fakultas Ekonomi dan Bisnis Universitas Pasundan, bilalfajar.bf@gmail.com
}

\begin{abstract}
ABSTRAK
Mengetahui pola konsumsi dan faktor yang memengaruhi konsumsi wisatawan di suatu daerah adalah salah satu kunci sukses dalam mengelola destinasi wisata setingkat kota seperti halnya Kota Bandung. Walaupun faktanya hingga tahun 2018, kunjungan wisatawan ke Kota Bandung masih didominasi oleh wisatawan domestik, perencanaan dalam menarik lebih banyak wisatawan mancanegara untuk datang dan mengeluarkan pendapatannya, masih sangat relevan untuk disusun. Tujuan penelitian ini adalah menganalisis nilai dan jenis konsumsi wisatawan mancanegara di Kota Bandung, yang diwakili oleh wisatawan asal Malaysia sebagai turis asing yang paling banyak berkunjung. Pada akhir 2018 sebuah survey dilakukan terhadap 100 orang wisatawan yang sedang berkunjung di berbagai objek dan daya tarik wisata yang ada di Kota Bandung. Data yang diperoleh melalui kuesioner tersebut diolah dengan statistika deskriptif dan analisis faktor. Kebanyakan wisatawan berkunjung ke Bandung selama 3 hari 2 malam, dengan pengeluaran per orang sekitar Rp 4juta-Rp 5juta selama kunjungan tersebut. Pengeluaran tersebut terdiri atas pengeluaran sewa hotel, transportasi selama di Kota Bandung, makan dan minum dan souvenir. Analisis faktor menyimpulkan variabel pertama yang terbentuk dalam menjelaskan konsumsi wisatawan adalah faktor-faktor yang ada di dalam diri wisatawan dan variabel kedua yang terbentuk adalah faktor-faktor yang ada daerah tujuan wisata.
\end{abstract}

Kata Kunci: Pengeluaran wisatawan, jenis pengeluaran wisatawan, lama tinggal wisatawan

\begin{abstract}
Comprehending tourists expenditure pattern and factors affected the total consumption in specific region is the success key to manage tourist destination at the city level. Until 2018 tourists visit to Bandung had been dominated by domestic tourists but still it is important to plan how to increase the number of foreign travelers. This study analyzes the value and type foreign tourists' expenditure in the city of Bandung. At the end of 2018 a survey was conducted on 100 Malaysian tourists visiting various tourist objects and attractions, in the city of Bandung. The data compiled from questionnaire was processed by applying descriptive statistics and factor analysis. Most of the malaysian tourists spend 3 nights and 2 days in Bandung with average of expenditure $R p 4$ millions-Rp 5 millions during their stay. The total expenditure are composed of hotel payment, transportation cost in Bandung area, meal and souvenir purchases. Conclusion drawn from the factor analysis statistics is there are two factors constructed from the linkages between total amount of expenditure and its explaining indicators. The first is demand side factor and the second is supply side factor.
\end{abstract}

Keywords : tourists expenditure, types of tourist spending, tourist length of stay

\section{PENDAHULUAN}

Peran pariwisata dalam menyumbang pertumbuhan ekonomi negara berkembang semakin penting (Akan, 2007). Telah banyak penelitian sebelumnya yang meneliti faktor yang menentukan kunjungan wisatawan ke suatu daerah tujuan wisata (Abuamoud, Libbin, and Green 2014; Khuong and Nguyen 2018), faktor yang menentukan lama kunjungan wisatawan (Aguiló, Rosselló, and Vila 2017; Liang Wang, Davis Ka Chio Fong,

ISSN: 2355-6587, e-ISSN: 2528-2220

http://ejournal.bsi.ac.id/ejurnal/index.php/jp 
Rob Law 2017; de Menezes, Moniz, and Vieira 2008) dan faktor yang menentukan konsumsi wisatawan (Dora Smolčić Jurdana, 2016). Penelitian penelitian tersebut belum secara spesifik membahas perilaku konsumsi wisatawan dari negara tertentu yang berwisata di daerah tujuan wisata tertentu. Dalam celah pengetahuan penelitian terdahulu membuat penelitian ini dilakukan.

Dalam rapat koordinasi nasional III tahun 2018, Menteri Pariwisata RI menyatakan bahwa pemerintah menargetkan devisa sebesar US \$ 20 miliar pada tahun 2019 dengan target 20 juta kunjungan wisatawan mancanegara (Febrinastri, 2018). Artinya pemerintah menyimpan harapan besar sektor pariwisata terus berkembang yang ditunjukkan oleh indikator utama seperti jumlah kunjungan wisata, lama tinggal wisatawan dan konsumsi wisatawan. Salah satu daerah tujuan wisata yang diandalkan sebagai daerah tujuan wisata adalah Bandung dan sekitarnya. Walaupun demikian statistik menunjukkan turunnya kunjungan wisatawan ke Bandung dan sekitarnya dalam beberapa tahun terakhir. Pada tahun 2011, jumlah kunjungan wisatawan internasional dan wisatawan domestik masing-masing adalah 225.585 dan 6.712.824 wisatawan. Angka tersebut mengalami penurunan pada tahun 2016 menjadi 173.036 untuk wisatawan internasional dan 5.000.625 untuk wisatawan domestik (Pariwisata, 2018). Komposisi wisatawan internasional yang berkunjung ke Bandung berturut turut adalah Malaysia $73 \%$, Singapura $13 \%$, dan sisanya adalah $14 \%$. Wisatawan tersebut tinggal di Bandung selama 2,95 hari dan mengeluarkan Rp1,65 juta untuk turis Malaysia dan tinggal di Bandung selama 3,33 hari dan mengeluarkan Rp 3,2juta untuk turis Singapura (Pariwisata, 2018). Dalam upaya meningkatkan konsumsi wisatawan tersebut maka penelitian ini akan membahas apa saja yang menentukan konsumsi wisatawan di Kota Bandung. Selain itu penelitian ini diharapkan dapat menutup celah penelitian sebelumya yakni menganalisis relasi antara turis yang berasal dari daerah tertentu (Malaysia) di daerah tujuan wisata tertentu (Bandung dan sekitarnya).

\section{KAJIAN LITERATUR \\ Pengeluaran Wisatawan}

Pengeluaran wisatawan adalah pengeluaran total yang dilakukan oleh wisatawan ketika mengunjungi suatu daerah, dalam hal ini Bandung dan sekitarnya, untuk memenuhi kebutuhannya dalam bentuk barang dan jasa yang terkait dengan aktivitas wisatanya. Pengeluaran wisatawan menjadi salah satu tolok okor untuk menentukan dampak ekonomi dari perkembangan pariwisata di daerah tujuan wisata (Djulius and Syafutra, 2018; Wang, 2014)

\section{Jenis Pengeluaran Wisatawan}

Jenis pengeluaran wisatawan adalah klasifikasi pengeluaran wisatawan dari berbagai perspektif. Ada peneliti yang membaginya menurut akomodasi dalam perjalanan menuju destinasi wisata dan akomodasi selama di destinasi wisata (Aguiló, Rosselló, and Vila, 2017). Penelitian ini berfokus pada pengeluaran yang dilakukan selama wisatawan berada di daerah tujuan wisata yakni di Bandung dan sekitarnya. Masuk ke dalam klasifikasi ini sewa penginapan, makan dan minum, transportasi dalam kota, tiket masuk ke ODTW, souvenir, dan oleh oleh (gifts).

\section{Lama Tinggal Wisatawan}

Lama tinggal wisatawan adalah lama waktu antara kedatangan dengan kepulangan turis di daerah tujuan wisata. Ada beberapa pendekatan yang digunakan oleh penelitian terdahulu misalnya dengan mencatat waktu check in dengan waktu check out dari hotel. Penelitian ini, walaupun semua respondennya menginap di hotel/ penginapan, menanyakan waktu kedatangan (bahkan sebelum check in hotel) dan waktu kepulangan responden (bahkan sesudah waktu check out dari hotel). Bagi para peneliti, lama tinggal wisatawan dianggap sebagai batas waktu permintaan barang dan jasa yang dilakukan wisatawan (Thrane and Farstad, 2012).

Lama tinggal wsatawan dan pengeluaran wisatawan adalah dua hal yang saling terkait. Lama tinggal wisatawan seringkali dianggap sebagai faktor yang paling 
menentukan besarnya pengeluaran yang dilakukan wisatawan. Bila dilihat dari jenis pengeluarannya maka dapat dengan mudah ditelusuri bahwa memang ada pengeluaran yang langsung terkait dengan lam tinggal wisatawan di daerah tujuan wisata, seperti pengeluaran hotel, pengeluaran makan dan minum serta pengeluaran transportasi di dalam kota. Yang menentukan jenis dan jumlah pengeluaran wisatawan di daerah tujuan wisata pun beragam. Ada yang mengklasifikasikannya menurut sosio ekonomi wisatawan misalnya tingkat pendidikan wisatawan, kewarga-negaraan (Montilivi, 2015; Mudarra-Fernández, Carrillo-Hidalgo, and Pulido-Fernández, 2018). Selain itu ada pula yang mengklasifikasikannya melalui karakteristik perjalanan misalnya wisata alam, wisata budaya, wisata olah raga, MICE (Mudarra-Fernández, CarrilloHidalgo, and Pulido-Fernández 2018; Seyidov and Adomaitiene, 2016). Ada juga yang mengklasifikasikannya melalui karakteristik destinasi wisata misalnya imej daerah tujuan wisata, jarak antara kota asal wisatawan dengan tempat yang akan dikunjungi (Abuamoud, Libbin, and Green 2014; Mudarra-Fernández, CarrilloHidalgo, and Pulido-Fernández 2018)

Penelitian ini akan menjelaskan lebih mendalam tentang ketiga klasifikasi tersebut. Klasifikasi sosio ekonomi yang terkait dengan kewarganegaraan tidak lagi diteliti karena wisatawan yang diteliti semuanya berkewarganegaraan Malaysia. Yang ingin dijelaskan lebih mendalam adalah klasifikasi apa yang relevan untuk menjelaskan kunjungan wisatawan Malaysia di Bandung da sekitarnya.

\section{METODE PENELITIAN}

Populasi target dari penelitian ini adalah wisatawan asal Malaysia yang berwisata di objek daerah tujuan wisata (ODTW) yang ada di Kota Bandung. Survey dilakukan dalam kurun Juni-Juli 2018.

Ukuran sampel penelitian ditentukan berdasarkan jumlah kunjungan wisatawan asal Malaysia pada tahun 2016 yang tercatat oleh Badan Pusat Statistik Kota Bandung. Dengan ukuran populasi sebesar 121.000 dan margin of error $10 \%$, ditentukan ukuran sampel minimum untuk wisatawan asal Malaysia adalah 97 orang (dibulatkan menjadi 100 responden). Perhitungan ukuran sampel ini didasarkan pada rumus Sloven (Altares 2003). Pemilihan responden didasarkan pada prinsip pengambilan sampel acak berklaster (cluster random sampling) dengan mempertimbangkan ODTW yang sedang dikunjungi oleh wisatawan. Dari 5 jenis tipologi daya tarik wisata yang ada di Kota Bandung, dipilih 3 klaster yang relevan dengan penelitian ini yaitu wisata herritage, wisata belanja dna kuliner, serta wisata rekreasi dan hiburan.

Tabel 1:

Sebaran Responden

\begin{tabular}{lc}
\hline \multicolumn{1}{c}{ Jenis Daya Tarik } & $\begin{array}{c}\text { Jumlah } \\
\text { Responden }\end{array}$ \\
\hline Wisata herritage & 30 \\
Wisata belanja dan & 40 \\
kuliner & \\
Rekreasi dan hiburan & 30 \\
\hline
\end{tabular}
Sumber : Hasil Survey, 2018

Terhadap 100 responden tersebut disebarkan kusioner yang didalamnya terdiri atas pertanyaan tentang identitas responden, frekuensi kunjungan, tempat yang biasa dikunjungi,dan pengeluaran atau konsumsi selama berwisata.

Data yang diperoleh selanjutnya digunakan untuk analisis deskriptif serta analisis faktor. Analisis deskriptif dilakukan terutama untuk menganalisis besaran dan jenis konsumsi wisatawan, sedangkan analisis faktor dilakukan untuk mendapatkan faktor apa saja dan indikator apa saja yang ada di dalamnya, yang terbentuk dari konsumsi wisatawan selama di Bandung.

\section{PEMBAHASAN}

Seluruh responden adalah kepala rombongan atau kepala rumah tangga dari wisatawan yang terpilih menjadi respoden. Tabel 2 memperlihatkan statistik identitas responden penelitian ini.

Tabel 2 :

Identitas Responden

\begin{tabular}{lcc}
\hline Umur & $\leq 30$ tahun & $8 \%$ \\
& $>30$ tahun & $92 \%$
\end{tabular}

Pendidikan Undergraduate $66 \%$ 


\begin{tabular}{lll}
\hline & Post Graduate & $34 \%$ \\
Pekerjaan & $\begin{array}{l}\text { Pegawai Swasta } \\
\text { Wiraswasta }\end{array}$ & $53 \%$ \\
& Lainnya & $16 \%$ \\
Paket Wisata & $31 \%$ \\
& $2 D 1 N$ & $16 \%$ \\
& $3 D 2 N$ & $73 \%$ \\
& $4 D 3 N$ & $11 \%$ \\
Jumlah & 1 orang & $1 \%$ \\
Anggota & & \\
Kelompok & & \\
& 2 orang & $53 \%$ \\
& 3 orang & $46 \%$ \\
\hline S
\end{tabular}

Sumber : Hasil Survey, 2018

Melalui data yang tampak pada tabel 2 dapat disimpulkan bahwa kebanyakan kepala rombongan dari mereka yang datang ke Bandung berusia di atas 30 tahun, berpendidikan cukup tinggi dan memilih paket yang relatif cukup lama yakni 3 hari dan 2 malam dengan membawa 2-3 orang keluarga atau temanteman mereka. Artinya wisatawan asal Malaysia yang datang ke Bandung adalah mereka yang berpotensi melakukan konsumsi cukup banyak. Tabel berikut memberikan gambaran tentang motivasi kedatangan para wisatawan tersebut ke Kota Bandung.

Tabel 3 :

Konsumsi Wisatawan

\begin{tabular}{lll}
\hline Hotel/ & Rp600 ribu - & $70 \%$ \\
Penginapan & Rp800 ribu & \\
(per keluarga & $>$ Rp $800 \mathrm{ribu}$ & $30 \%$ \\
per hari) & & \\
\hline
\end{tabular}

\begin{tabular}{|c|c|c|}
\hline $\begin{array}{l}\text { Transportasi } \\
\text { (per keluarga } \\
\text { per hari) }\end{array}$ & $\begin{array}{l}\text { Rp } 750-850 \text { ribu } \\
>\text { Rp } 850 \text { ribu per } \\
\text { keluarga per hari }\end{array}$ & $\begin{array}{c}98 \% \\
2 \%\end{array}$ \\
\hline $\begin{array}{l}\text { Makan dan } \\
\text { Minum }\end{array}$ & $\begin{array}{l}\text { Rp 250-Rp } 300 \\
\text { ribu }\end{array}$ & $72 \%$ \\
\hline $\begin{array}{l}\text { (per orang } \\
\text { per hari) }\end{array}$ & $>$ Rp 300 ribu & $28 \%$ \\
\hline
\end{tabular}

\begin{tabular}{llc}
\hline \multirow{3}{*}{ Belanja } & $<$ Rp 4 juta & $10 \%$ \\
& Rp4jt - Rp $8 \mathrm{jt}$ & $85 \%$ \\
& $>$ Rp $8 j t$ & $5 \%$ \\
\hline
\end{tabular}

Total $\quad R p 5 j t-R p 9 j t \quad 19 \%$

\begin{tabular}{llc} 
Konsumsi & $\begin{array}{l}\text { Rp10jt }- \text { Rp 14jt } \\
>\text { Rp14 jt }\end{array}$ & $67 \%$ \\
& & $14 \%$ \\
\hline Jumlah & 1 orang & $1 \%$ \\
Anggota & 2 orang & $53 \%$ \\
Kelompok & 3 orang & $46 \%$ \\
\hline
\end{tabular}

Sumber : Hasil Survey, 2018

Dari tabel 3 dapat diketahui bahwa jenis pengeluaran yang dinyatakan oleh responden adalah penginapan, transportasi, makan dan minum, dan belanja (gift dan souvenir). Klasifikasi ini sesuai denngan apa yang telah dinyatakan oleh peneliti penelitia sebelumnya (Dora Smolčić Jurdana 2016; Mudarra-Fernández, Carrillo-Hidalgo, and Pulido-Fernández 2018). Dilihat dari besaran pengeluaran yang dilakukan responden, mereka termasuk kelas menengah bila dipadanankan dengan penduduk Indonesia. Alasannya adalah kebanyakan dari mereka memilih tinggal di penginapan dengan tarif Rp 400 ribu per malam yang setara dengan tarif hotel bintang 3. Kebanyakan dari mereka menyewa mobil untuk beriwisata di dalam dan sekitar Kota Bandung dengan biasa sewa Rp 750 ribu per hari. Untuk 2 kali makan per hari, para responden menghabiskan Rp 250 ribu per orang per hari.

Yang menarik adalah para responden mengeluarkan uang Rp4 juta-Rp8 juta untuk gift dan souvenir. Angka ini cukup tinggi bila dibandingkan dengan pengeluaran lainnya, bahkan bila angkanya dibagi dengan jumlah anggota keluarga atau anggota tim. Besarnya angka ini karena kebanyakan mereka membeli baju atau produk garmen yang memang penjualnya sangat banyak dan menjadi salah satu ciri khas Kota Bandung. Ada kemungkinan beberapa dari wisatawan ini membeli produk garmen untuk dijual kembali, bukan hanya untuk keperluan sendiri.

\section{Analisis Faktor}

Analisis faktor dilakukan untuk mengklasifikasikan indikator-indikator yang ditanyakan dalam kuesioner menjadi faktor yang menentukan konsumsi wisatawan asal Malaysia di Kota Bandung. Ada beberapa indikator yang disertakan yakni indikator yang berkaitan dengan

ISSN: 2355-6587, e-ISSN: 2528-2220

http://ejournal.bsi.ac.id/ejurnal/index.php/jp 
responden seperti usia, jenis kelamin, pendidikan terakhir, pekerjaan. Selain itu ada juga indikator yang berkaitan dengan ODTW yang dikunjungi yaitu jenis wisata, objek wisata yang dikunjungi dan souvenir yang dibeli.

Metode yang digunakan adalah principal component analysis yang didahului dengan menguji apakah faktor yang berhasil direduksi telah lolos uji kebaikan model melalui uji KMO dan Uji Bartlett. Statistik KMO diperoleh sebesar 0,548 yang menunjukkan kecukupan dari sampel $(>0,5)$. Selain itu chi-square diperoleh sebesar 251,11 dengan nilai signifikansi 0,00 menunjukkan kecukupan dari sampel.

Tabel berikut menunjukkan hasil perhitungan komponen matriks yang dilakukan.

Tabel 4 :

Component Matrix Konsumsi Wisatawan Asal Malaysia

\begin{tabular}{lccc}
\hline & \multicolumn{3}{c}{ Component } \\
\cline { 2 - 4 } & 1 & 2 & 3 \\
\hline Usia & $\mathbf{. 6 7 1}$ & .215 & -.015 \\
Jenis Kelamin & -.687 & -.221 & -.204 \\
Pendidikan & .796 & .227 & -.018 \\
terakhir & $\mathbf{6 9 7}$ & .029 & -.349 \\
Pekerjaan & -.223 & .939 & .004 \\
Jenis Wisata & & & \\
$\begin{array}{l}\text { Objek Wisata } \\
\text { Yang dikunjungi }\end{array}$ & .077 & -.264 & .388 \\
$\begin{array}{l}\text { Oleh oleh yang } \\
\text { dibeli }\end{array}$ & -.058 & -.559 & .714 \\
$\begin{array}{l}\text { Souvenir yang } \\
\text { dibeli }\end{array}$ & .317 & .739 & .444 \\
\hline
\end{tabular}

Sumber : Pengolahan Data, 2018

Pada tabel 4 tampak bahwa faktor 1 memiliki korelasi kuat dengan usia responden, pendidikan responden, dan pekerjaan responden karena ketiga faktor tersebut memiliki korelasi di atas 0,5. Selain itu, faktor kedua memiliki korelasi kuat dengan jenis wisata dan suvenir yang dibeli oleh wisatawan.

Setelah dapat diekstrak 2 faktor dengan masing-masing variabel pembentuknya maka langkah selanjutnya adalah memberikan nama terhadap faktor tersebut.
Penelitian ini memberi nama variabel pertama dengan faktor internal wisatawan. Nama ini diberikan dengan pertimbangan bahwa ketiga variabel yang berkorelasi tinggi dengan faktor pertama adalah karateristik responden. Variabel kedua yang terbentuk diberi nama karakteristik daerah tujuan wisata karena memang jenis wisata dan suvenir yang dibeli berkaitan dengan daerah tujuan wisata yang dikunjungi. Dengan demikian penelitian ini bukan hanya mengkonfirmasi penelitian sebelumnya tenang berbagai klasfikasi faktor penentu pengeluaran wisatawan, tapi juga menjelaskan klasifikasi yang relevan untuk kunjungan wisatawan di Bandung adalah faktor internal wisatawan dan karakteristik daerah tujuan wisata (Dora Smolčić Jurdana 2016; Khuong and Nguyen 2018; Loon and Rouwendal 2017; Montilivi 2015).

Makna yang tersirat dari anlaisis faktor ini adalah pentingnya menetapkan target wisatawan berdasarkan usia tertentu, pendidikan tertentu (undergraduate) dan pekerjaan wisatawan (pegawai swasta) untuk pasar turis dari negara lainnya. Selain itu hasil penelitian ini juga mengungkapkan pentingnya mengelola objek daerah tujuan wisata dengan karakteristik tertentu dalam menarik wisatawan mancanegara.

\section{PENUTUP}

Wisatawan asal Malaysia di Kota Bandung yang bepergian dengan berkelompok kebanyakan dipimpin oleh mereka yang berusia 30-40 tahunan. Merekalah yang menjadi penentu (decision maker) atas konsumsi dan pengeluaran yang dilakukan oleh kelompok kecil tersebut. Karaketeristik lainnya adalah mereka berpendidikan undergraduate, karyawan swasta, berasal dari kalangan pendapatan menengah, berwisata selama 3 hari 2 malam. Pengeluaran yang mereka lakukan rata-rata sebesar Rp4juta-Rp 5juta per orang selama mereka berada di Bandung. Pengeluaran utama mereka dikelompokkan ke dalam pengeluaran hotel, makan dan minum, transportasi dan belanja. Faktor yang menentukan belanja wisatawan dikelompokkan ke dalam faktor yang 
berasal dari internal wisatawan dan faktor karakteristik daerah tujuan wisata.

\section{REFERENSI}

Abuamoud, Ismaiel Naser, James Libbin, and Janet Green. 2014. "Factors Affecting the Willingness of Tourists to Visit Cultural Heritage Sites in Jordan." Journal of Heritage Tourism (September): 37-41.

Aguiló, Eugeni, Jaume Rosselló, and Mar Vila. 2017. "Length of Stay and Daily Tourist Expenditure: A Joint Analysis." Tourism Management Perspectives 21: 10-17. http://www.sciencedirect.com/scienc e/article/pii/S2211973616301003.

Akan, Yusuf; İ brahim Arslan; Cem Isk. 2007. "The Impact of Tourism on Economic Performance: The Case of Turkey." Journal of Tourism 9(1): 124.

Altares, Priscilla S. 2003. Elementary Statistics: A Modern Approach. Manila: Rex Book Store.

Djulius, Horas, and Ricky Syafutra. 2018. "Lama Tinggal Wisatawan Nusantara Di Bandung." Jurnal Akuntansi \& Ekonomi ( JAE ) 4(1): 75-86.

Dora Smolčić Jurdana, Daniela Soldić Frleta. 2016. "Factors Affecting The Expenditure Of Domestic And Foreign Tourists - The Evidence From Rijeka And Opatija, Croatia." In Tourism \& Hospitality Industry 2016, , 418-31.

Febrinastri, Fabiola. 2018. "No Title."

Suara.com.

www.suara.com/bisnis/2018/09/27/1

50000/menpar-pariwisata-

merupakan-sektor-andalan-penghasildevisa.

Khuong, Mai Ngoc, and Pham Anh

Nguyen. 2018. "Factors Affecting

Tourist Destination Satisfaction and

Return Intention - A Study in Ho Chi

Minh City, Vietnam." Journal of

Economics, Business and

Management 5(2): 95-102.

Liang Wang, Davis Ka Chio Fong, Rob

Law, Bin Fang. 2017. "Length of

Stay: Its Determinants and

Outcomes." Journal of Travel
Research 57(4): 472-82.

Loon, Ruben, and Jan Rouwendal. 2017.

"Travel Purpose and Expenditure

Patterns in City Tourism : Evidence

from the Amsterdam Metropolitan."

Journal of Cultural Economics 41(2): 109-27.

de Menezes, António Gomes, Ana Moniz, and José Cabral Vieira. 2008. "The Determinants of Length of Stay of Tourists in the Azores." Tourism Economics 14(1): 205-22.

Montilivi, Campus. 2015. "Determinants in Tourist Expenditure Composition - the Role of Airline Types."

Tourism Economics 21(1): 9-32.

Mudarra-Fernández, Ana Belén, Isabel Carrillo-Hidalgo, and Juan Ignacio Pulido-Fernández. 2018. "Factors Influencing Tourist Expenditure by Tourism Typologies: A Systematic Review." Anatolia: 1-17. https://doi.org/10.1080/13032917.201 8.1495086 .

Pariwisata, Kementerian. 2018. Kapasitas Layanan Destinasi Pariwisata Bandung Dan Sekitarnya.

Seyidov, Javid, and Roma Adomaitienè. 2016. "Factors Influencing Local Tourists' Decision-Making On Choosing A Destination : A Case Of Azerbaijan." ekONOmIka 95(3): 112-27.

Thrane, Christer, and Eivind Farstad. 2012. “Tourists' Length of Stay: The Case of International Summer Visitors to Norway." Tourism Economics 18(5): 1069-82.

Wang, Ying. 2014. "A Review of MicroAnalyses of Tourist Expenditure A Review of Micro Analyses of Tourist Expenditure." Current Issues in Tourism 13(6): 1-32.

\section{BIODATA PENULIS}

Horas Djulius, Doktor bidang ilmu ekonomi dari Universitas Padjadjaran. Sejak 1996 menjadi dosen tetap dan mengajar di Fakultas Ekonomi dan Bisnis Universitas Pasundan. Selain itu juga mengajar di Program Studi Magister Manajemen dan Program Studi Doktor

ISSN: 2355-6587, e-ISSN: 2528-2220

http://ejournal.bsi.ac.id/ejurnal/index.php/jp 
Ilmu Manajemen di universitas yang sama. Hingga manuskrip ini dibuat telah ada beberapa penelitian yang dilakukan olehnya dengan topik ekonomi pariwisata, ekonomi kreatif dan industri kreatif.
Bilal Fajar Nugraha, sarjana ekonomi dari Fakultas Ekonomi dan Bisnis Universitas Pasundan. Telah melakukan penelitian dengan topik pariwisata terutama wisatawan mancanegara dari Malaysia dan Singapura yang mengunjungi Kota Bandung. 